\title{
Institutionalization of Research Administration in Brazil: Some Evidences
}

\author{
Fernanda Stringassi de Oliveira ${ }^{I^{*}}$, Maria Beatriz Machado Bonacelli ${ }^{2}$
}

\begin{abstract}
The arrangement of different research institutions and partners, including public funding agencies, is mandatory to address the current science, technology and innovation challenges. The access and maintenance of research collaboration networks require high level of competence and efficiency by the organizations. The multidisciplinary and multi-institutional research projects require management and administrative activities to achieve project goals in the expected time and cost, and the Research Administration (RA) professionals can be an important facilitator in the implementation of a governance strategy. The two case studies presented in this article illustrates the creation of RA institutional elements in Brazil that is evidence of the willingness to face the bureaucracy and practical consequences of the disconnection of science, technology and innovation policy actors. The searching for more efficiency and impacting results is directly related to the bureaucracy and transaction costs minimization and the maturity of the STI institutional and governance structure.
\end{abstract}

Keywords: research administration; transaction costs; research funding.

Submitted: January $29^{\text {th }}, 2019 /$ Approved: June $14^{\text {th }}, 2019$

\section{Introduction}

This paper will present the current context of Research Administration (RA) and some evidences of institutionalization of the area in Brazil, discussing the potential of these initiatives to improve the efficiency of Science, Technology and Innovation (STI) projects.

While the global Research and Development (R\&D) capacity doubled in the period from 2001 to 2016, the expansion of business R\&D expenditure is facing a slowdown due to the recent weak economic performance, that scarce government budget and resources competition. National governments are, in the most of the cases, the main funder of public research and the tendency is that they continue to be, although business financial contribution and public-private partnerships remain necessary as alternative sources of funding in this cases. Moreover, the focus of science and technology agenda has shifted to societal and environmental challenges since early 2000s, and, boosted by the recent 2030 Agenda for Sustainable Development of the United Nations, reinforced the relevance of the public research, with business partners participation, to the progress of the socioeconomic development (OECD, 2016).

Research projects must enable the combination of traditional and distant academic fields (e. g. Physics and Social Sciences) to face the coming challenges since "many of the most significant breakthroughs in science and technology have come at the interfaces between disciplines" (OECD, 2016, p. 137). Furthermore, new research fields are expected to emerge from the combination of current technologies such as cognitive sciences and information and communication technologies. The increasing connections among contemporary technologies and socioeconomic changes bring the necessity of continuing renovation of the Science and Technology Institutions as the relevant component of the Innovation System (IS). The arrangement of diffe- rent research agencies and actors must the considered in the strategic research priorities to join and combine capacities (Albuquerque \& Bonacelli, 2014; OECD, 2016).

Chesbrough (2006, p. 3) called as "Open Innovation" the process of combine internal and external ideas to advance firms technology and internal and external paths to market, considering $\mathrm{R} \& \mathrm{D}$ as an open system. The author also affirms that "R\&D organizations must identify, connect to, and leverage external knowledge sources as a core process in innovation". Informal networks among researchers and institutions have always been present in the science and technology organization (OECD, 1992), but since the 1970s the "strategic technology partnering" (STP), which means, the collaborations among competitors, suppliers, customers, universities and others, has increased (Hagedoorn, 2002; Narula \& Zanfei, 2005). There are also strategic and cost saving motives to the establishment of STPs such as cost and risk sharing, infrastructure sharing and knowledge acquisition about new markets (e. g. other regions or countries knowledge and regulatory specificities). After the 1980s there is an expressive acceleration in STP growing due to "increased complexity of scientific and technological development, higher uncertainty surrounding $R \& D$, increasing costs of $\mathrm{R} \& \mathrm{D}$ projects, and shortened innovation cycles" (Hagedoorn, 2002).

The process of institutional reorganization of R\&D is impacted by globalization, budget restrictions, limited resources and the STI complex environment. The access and maintenance of research collaboration networks require high level of competence and efficiency by the institutions and organizations in several areas such as managerial and organizational besides technical and scientific (Salles-Filho, Bonacelli, \& Mello, 2000). Research projects executed in collaboration, mainly with public or private funding, usually follow specific management and administration processes, different from internal

1) Embrapa Agricultural Informatics, Campinas-SP, Brazil, and Scientific and Technological Policy Department, Institute of Geosciences, University of Campinas - UNICAMP, Campinas-SP, Brazil.

2) Scientific and Technological Policy Department, Institute of Geosciences, University of Campinas - UNICAMP, Campinas, SP, Brazil.

*Corresponding author: E-mail: fernanda.oliveira@embrapa.br 
operational processes of the respective research institutions. The additional knowledge required to prepare project proposals and manage awarded research projects inhibits the prospection of funding opportunities by researchers (Cunningham, O’Reilly, O’Kane, \& Mangematin, 2014).

Salles-Filho and Bonacelli (2010) highlighted four empirical elements that impact the effectiveness of research organizations: funding strategy and leverage of resources; work sharing, including creation and participation in STI networks; knowledge appropriation and technology transfer; and attraction and maintenance of human resources. The conducted study concluded that Brazilian institutions are forced to search other funding sources, but, simultaneously, the culture of $R \& D$ management is very weak due to an absence of internalized routines related to partnering, negotiation, intellectual property management and impacting evaluation in the most of public research organizations. A comparative study conducted by Bin et al. (2013) in four public research institutions from several countries including Brazil, concluded that even though public research institutions have been reorganizing their innovation processes, there is still a separation among R\&D and partnership structures and policies. They also noted that the studied institutions are strongly engaged in partnerships but few of these initiatives are related to extramural research funding.

A study about "What does Brazilian researcher think about bureaucracy?", published by National Council of Foundations to Support Federal Institutes of Higher Education and Scientific and Technological Research (CONFIES) pointed that a researcher spends, in average, $33 \%$ of his time to solve red tape issues related to complexity and excessive regulation, management, and procurement difficulties. These obstacles increase national research cost and decrease Brazilian competitiveness internationally (CONFIES, MCTIC, \& SEBRAE, 2017; Monteiro, 2017). In general, these intrinsic challenges of STI environment are enlarged by the Brazilian context due to historical aspects of the socioeconomic development and delayed scientific and technical progress (De Negri, Zucoloto, Squeff, \& Rauen, 2016).

The new structure created to coordinate research activities and sustain the research excellence demanded by the new conjecture was called Research Administration (RA). The RA professional is the mediator for different parties in the research process (institution, researcher and sponsor) and responsible for three basic functions performed along research lifecycle, from pre-award phase (before grants or scholarship approval by funding agency) until post-award phase, and also crosswise the research institution and partners: overall administration of research institutions, provision of services for researchers, and support sponsors in goals achievement and compliance (Beasley, 2006). Most of the time, administrate a research project requires knowledge that the principal investigator doesn't have, which results in a waste of time and effort that is considered a burden to the scientific professionals already overwhelmed with technical activities.

STI planning and management processes have specificities: indeterminacy due to $R \& D$ and innovation activities uncertainty and high unpredictability; profile of the professionals involved and organizational culture shared by them; and multi-institutionality.
Such specificities request support and coordination structure to deal with researchers autonomy, team conflicts and institutions and partners relationship in knowledge production and appropriation (Bin \& Salles-filho, 2008). In general, the multidisciplinary and multiinstitutional projects require management and administrative activities to be able to achieve project goals in the expected time and cost. Transaction Costs Economy (TCE) is an appropriate framework for the analysis of the STI processes as also strategic decisions regarding governance structures related to integration, contracting and collaboration in R\&D and Technology Transfer (TT) activities (Bin \& Salles-filho, 2008) and will be used as theoretical approach to support this study.

The paper objective is to discuss the impact of RA activities to minimize transaction costs in research institutions and their research projects and also the potential impact of the development and institutionalization of RA for STI in Brazil. The justification of this study is to contribute and stimulate knowledge building about Research Administration area and its impacts in Brazil.

Initially, it is presented a literature review about RA history since the postwar period until today, and the role of professional associations in the empowerment and recognition of the research administrator professional abroad. Next, the literature review also contemplates the identification of some events in Brazilian history that contributed to the establishment of a favorable environment for RA development such as the creation of public funding agencies for science and technology, and also brings an overview of some Brazilian STI challenges regarding regulations, red tape, and its inexpressive innovative results. In the sequence, the argumentation will be based in two case studies that illustrate recent events that are significant steps in the construction of the RA history in Brazil: the "Training Program for Implementation of an Institutional Support Office for Researchers (EAIP)” of the São Paulo Research Foundation (FAPESP), and the creation of the Brazilian Research Administration and Management Association (BRAMA).

\section{Research Administration Historical Review and Current Context}

\subsection{History of Research Administration}

The post-World War II "Big Science era" consolidated the role of the State in the research funding. The report "Science the Endless Frontier" officialized the importance of the science and technology for the economic development and proposed a new role and mechanism to the government to maintain incentives to research in industry and universities (Bush, 1945). As one of several outputs of Vannevar Bush's report, in 1950 the US government created the National Science Funding (NSF), agency focused in basic research projects. In a short time, with the rapid advances of the science and its consequent political success, other science agencies were created or continued, establishing the American network of federal basic research agencies, a large and pluralistic system that is still active (Beasley, 2006; Bonvillian, 2014). All these achievements were the result of the succeeded experience of Vannevar Bush in the direction of the Office of Science Research and Development (OSRD) in the National Defense Research Council (NDRC) where he was responsible for the creation of a central structure to coordinate and support the national scientific research program (Beasley, 2006). 
Arrow (1972) explained in detail the uncertainty and consequent risk involved in the invention process that is the reason behind the importance of the government participation in the research funding. The basic research generates informational input to other research activities and it is unlikely to be rewarded or have commercial value, and, therefore, is usually conducted outside the industrial system. Driven by military needs and the legitimacy of science as an essential key to social and economic development, a new political economy of science was put in place investing in large-scale projects, also called "Big Science". Such term was firstly introduced in the article "Impact of Large-Scale Science on the United States", in which Weinberg (1961) also highlighted a relevant effect of large-scale support of science, that is the huge amount of public money that must be wisely administrated and spent. The author recognized at that time the importance of nonscientific roles such as journalism, publicity, finance and administrative people in the staff of these big projects. He expressed concern with the confirmation that large-scale $R \& D$ projects were not only happening in industry or laboratories, but also in universities, and consequent burden of science administration to college professors.

Big Science projects have "led to a large-scale development of contractual relations between producers and a buyer of invention and research" and brought a different economic relation: payment is independent of product and assures efficiency would be a challenge (Arrow, 1972, p. 624). Due to the need to administrate such big research programs, OSRD needed to have people allocated in the management of nonresearch requirements (e. g. contracting, purchasing, accounting, and reporting). At that occasion, the research scientists were trained to be research administrators.

Before 1945, the low amount of financial support didn't create a need for research administration at that moment. But in the postwar period, the science in the US was supported by federal government agencies, universities, industrial research laboratories and private foundations through grants to institutions and individuals (e. g. Rockefeller Foundation). The relevant flow of money required more caring regarding institutional research policy, projects application and procurement process, financial and reporting requirements of the sponsors and research program coordination, that brought the necessity of skilled people and the establishment of research administrative systems. Seizing the opportunity, the research institutions and universities faced a race to attract research, build facilities and ensure contracts and grants maintenance (Beasley, 2006).

Then, in short time, organizations to discuss research administration practices and share knowledge were created. The first organization, The National Conference on the Advancement of Research (NCAR) was created in 1947; NCAR participants were the pioneers of research administration. In the 1959 annual meeting the idea of a new association specific for university research administrators was conceived and then, National Council of University Research Administrators (NCURA) were created. In 1967, the Society of Research Administrators International (SRAi) was founded after a meeting that occurred at NCAR in 1966. Followed by the creation of the Canadian Association of University Research Administrators (CAURA) in 70's, together with NCURA and SRAi these were the only associations until the beginning of the 1990s (Beasley, 2006).

\subsection{Research Administration Associations}

Professional associations contribute to the sharing, definition and promulgation of values, beliefs and norms since they are key arenas for networking and creation of a professional subculture (Galaskiewicz, 1985). Based in Wright (1988), having in mind the concepts regarding "policy community" and "policy network" and the goal of this paper, it is important to emphasize that the RA associations are not only a professional network but also an important policy community in the STI policy network.

The review of literature performed in 2018 identified 22 active associations distributed in all continents of the globe (see Table 1). As already described, the North American associations NCURA and SRAi were the pioneers. Formally created in 2015, the Brazilian association is one of the most recent (BRAMA, 2018a). There are some associations that represent a network of regional or global associations, such as International Network of Research Management Societies (INORMS). 
Table 1. List of Research Administration and Management Associations.

\begin{tabular}{|c|c|c|c|}
\hline $\begin{array}{c}\text { Creation } \\
\text { Year }\end{array}$ & Region/Country & Continent & Association \\
\hline 1959 & US and Internacional & North America & National Council of University Research Administrators (NCURA) \\
\hline 1967 & US and Internacional & North America & Society of Research Administrators International (SRAI) \\
\hline 1975 & Canada & North America & Canadian Association of University Research Administrators (CAURA) \\
\hline 1989 & Canada & North America & Canadian Association of Research Administrators (CARA) \\
\hline 1991 & United Kingdom & Europe & Association of Research Managers and Administrators (ARMA) \\
\hline 1994 & European countries & Europe & European Association of Research Managers and Administrators (EARMA) \\
\hline 1999 & Oceania countries & Oceania & Australasian Research Management Society (ARMS) \\
\hline 2001 & Global & All continents & International Network of Research Management Societies (INORMS) \\
\hline 2002 & South Africa & Africa & Southern African Research and Innovation Management Association (SARIMA) \\
\hline 2003 & Germany & Europe & German Asociation for Research Managers and Administrators (GARMA) \\
\hline 2007 & West Africa & Africa & West African Research and Innovation Management Association (WARIMA) \\
\hline $2007^{\star}$ & Netherlands & Europe & Association for Research Managers and Administrators - the Netherlands (ARMA-NL) \\
\hline 2009 & Denmark & Europe & Danish Association of Research Managers and Administrators (DARMA) \\
\hline 2009 & African countries & Africa & Association of Research Administrators in Africa (ARAA) \\
\hline 2010 & Caribbean countries & Latin America & Caribean Research \& Innovation Management Association (CabRIMA) \\
\hline 2011 & East Africa & Africa & Eastern African Research and Innovations Management Association (EARIMA) \\
\hline 2012 & Finland & Europe & Finnish Association of Research Managers and Advisors (FInn-ARMA) \\
\hline 2012 & Iceland & Europe & Icelandic Association for Research Managers and Administrators (ICEARMA) \\
\hline 2013 & Norway & Europe & Norwegian Network for Administration and Research Management (NARMA) \\
\hline 2015 & Uganda & Africa & Uganda Research and Innovation Management Association (URIMA) \\
\hline 2015 & Japan & Asia & Research Manager and Administrator Network Japan (RMAN-J) \\
\hline 2015 & Brazil & Latin America & Brazillian Association of Research Managers and Administrators (BRAMA) \\
\hline
\end{tabular}

${ }^{*}$ Formerly called EUPMAN, the association was renamed in 2018 (EUPMAN, 2018).

Source: Elaborated by the author based in data collected from INORMS members page, associations websites or related paper (ARMA, 2018; ARMS, 2018; BRAMA, 2018a; CARA, 2018; CAURA, 2018; DARMA, 2018; EARIMA, 2018; EARMA, 2018; EUPMAN, 2018; Finn-ARMA, 2018; ICEARMA, 2018; INORMS, 2018; NARMA, 2018; NCURA, 2018; RMAN-J, 2017; SARIMA, 2018; SRAi, 2018; Streete, Henry, Ivey, \& Oliver, 2013; URIMA, 2018; WARIMA, 2018).

\subsection{Research Administration Professional}

Although the amount of R\&D expenditures and priorities are always changing due to political context, the basic RA core of knowledge is constant (Kulakowski \& Chronister, 2008). The RA activities contemplates four areas, according to Certified Research Administration Body of Knowledge (RACC, 2018): project development and administration (collection and dissemination of information, proposal development, administration of awards, ethics and professionalism, intellectual property); legal requirements and sponsor interface (regulation, compliance); financial management (accounting, costs, financial reporting, audit); and general management (facility management, contracts and purchasing, records management, human resource management). Since RA activities are varied and added by STI specificities, the research administrators have diverse origin, formation, work area (e. g. pre-award, compliance, technology transfer, finance) and responsibility level (e.g. vice president, contract negotiator, department secretariat) (Landen \& McCallister, 2008).

A research project called "Research Administration as a Profession" (RAAAP) was coordinated by Kerridge and Scott (2018)and involved several associations in the constitution of an advisory board to prepare and run the most adequate questionnaire to map the profile of the RA professional. The research was performed in 2016 and collected 2691 responses of research administrators from 64 countries. The study participants were members of associations and mostly females acting as RA manager or leader. US had the highest quantity of respondents with over 20 years of experience, while the rest of the world (participants of a group of less expressive RA associations, that includes Brazil) has the highest proportion of respondents with less than 5 years of experience. Additionally, there was a lower quantity of full-time RA in the rest of the world compared to US, Canada, Europe, Australia and New Zealand, which means that in these locations the RA activities were usually an additional duty in another function. Finally, the result of the study confirmed the current global coverage of the profession although has also mentioned the difference of maturity among regions.

\subsection{History of Research Funding in Brazil}

Brazil did not start late in the establishment of some important agencies for science and technology compared to the US, even with a totally diverse socioeconomic environment, pushed by the Import Substitution Industrialization (ISI) and consequent demand to technology and know-how. The Brazilian Society for the Advancement of Science (SBPC), created in 1948, was the first scientific association and achieved 352 members only in the first year. Based in promise of "science as production force" in a context of industrial development and nationalist ideology, the science policy is institutionalized with the creation of Brazilian National Research Council (CNPq) and Coordination for Improvement of Higher Education Personnel (CAPES) in 1951. These achievements enabled the development of career in science, providing scholarships and grants to full-time researchers and students. Unfortunately, in the followed decade the budget of such funding agencies decreased and with the increase of the foreign capital investment, the relation of science and industry has become much more distant. In late 60's and 70's occurred an additional tentative to strengthen technological and scientific development with the creation of governmental fund for science and technology development and Public Research Institutions such as Brazilian Agricultural Research Corporation (EMBRAPA) and Brazilian Aeronautical Company (EMBRAER) (Morel, 1979; J. J. De Oliveira, 2016; SBPC, 2016).

Since then the fund for science and technology development never have achieved the expected budget and economic instabilities have just been aggravated which led to impede any constancy to the STI 
budget. But even with contingencies and low performance and efficiency of the fund, in 2000 and followed years, the finance amount of such fund have increased significantly (50\% in 2001 and $30 \%$ in 2002) (Bastos, 2003). Additionally, a legal framework of tax incentive to $\mathrm{R} \& \mathrm{D}$ investment by companies was created since 90 's as detailed by Pacheco (Pacheco, 2011). Moreover, Brazilian agenda prioritized innovative actions since the 2000's when new legal instruments such as Innovation Law (10.973/2004) was established (Pacheco, Bonacelli, $\&$ Foss, 2017). Although the questionable efficiency of such initiatives discussed by the cited authors, the finance amount and partnerships established for R\&D and innovation projects have increased in Brazil and reinforced the necessity of adequate administration of the research projects and their resources by the STI institutions. Indicators of the Science, Technology, Innovation and Communication Ministry (MCTIC) presented an amount of more than $\mathrm{R} \$ 12$ billion in 2000 and more than R\$76 billion in 2015 in R\&D expenditures (MCTIC, 2018).

\subsection{Current Challenges of R\&D and Innovation in Brazil}

The 2014 Survey of Innovation (Pintec) performed by the Brazilian Institute of Geography and Statistics (IBGE) indicated maintenance of the innovation rate (IBGE, 2016). The survey presented the following factors as the main obstacles for innovation by companies: cost $(86 \%$ of the industries), risks $(82,1 \%)$ and scarce funding sources for innovative activities $(68,8 \%)$. The tax incentives to stimulate R\&D investment by companies have limited coverage because of several causes such as unfamiliarity with these incentives and inexistence of innovation strategy by Brazilian companies due to low pressure of local market for differentiation by disruptive innovation (Carvalho, 2010). Pintec also indicated increase in the percentage of product innovations resulted from partnerships with other companies or research institutes from 2011 to 2014, although the percentage of partnerships established by industries had a low decrease $(15,9 \%$ in 2011 and 14,3\% in 2014). Currently, it is generally expected that public research sponsored by funding agencies achieves socioeconomic impact in addition to scientific impact, therefore technology transfer success is also an important activity to generate services, product and process innovation (Cunningham et al., 2014).

The most of the governmental initiatives offer financial resources and tax incentive without favorable socioeconomic conditions and without a continuous strategy to build and retain innovative capacity including knowledge, infrastructure and skilled researchers (Pacheco et al., 2017). The market conditions are the main reason why the companies do not innovate, according to Pintec.

Although no significative progress in R\&D and innovation indicators in the last years, Brazil has had relevant advancements in the last decades that built an important STI infrastructure and institutional environment that need to be maintained and continually evolved. Most of them are dependent on public or private funding. A survey about the Brazilian Science and Technology infrastructure coordinated by De Negri and Squeff (2014) identified 1760 infrastructures including laboratories, monitoring stations, observatories, and pilot plants, and more than $23 \%$ of them initiated their activities after 90 's and $56 \%$ after 2000's. About 7000 researchers work in the mapped insfrastructure and
5814 people in the technical and administrative support. The authors also mentioned the importance of public funding collaboration to the implementation of such infrastructures. Another indicator of Brazilian scientific results is the Scimago Journal \& Country Rank that shows Brazil in $14^{\text {th }}$ position in the number of academic publications and $24^{\text {th }}$ position in H-index rate in 2017 (SJR, 2018).

It is important to notice that at the same time that the lead researcher has prestige when his project is granted, he also incorporates several additional duties that sometimes he is not prepared or motivated to do, such as team supervision, schedule management, technical documentation and progress reporting, finance control, contracts management, and others, while have to deal with dual sets of control mechanisms and bureaucracies: of his own institution and of the funding agency (Cunningham et al., 2014; F. S. de Oliveira, Bambini, Spatti, \& Ito, 2017). The previously mentioned survey about bureaucracy in research activities received 301 responses from Brazilian researchers (CONFIES et al., 2017). According to it, $69 \%$ of the participants answered that red tape related to submit and manage STI projects increased in the last years, $85 \%$ answered that research project management activities are complex and demand much effort and time, $49 \%$ answered that project management represents $30 \%$ to $40 \%$ of the total time spent, and $39 \%$ answered that don't know the last changes in STI laws and regulations.

Based in the several facts described before, we can summarize that public funding is mandatory to the continuity of the advancement of science in Brazil, and that it is very important that research institutions and companies know how to have access to funding opportunities and tax incentives and how to manage adequately the resources received. STP and intellectual property management are also relevant to develop and disseminate impacting discoveries or innovation. We can also assume that effort in administration and management of research projects and infrastructure is obviously mandatory, and it is already done in Brazilian institutions in a higher or low efficiency according to their capacity. The RA can have an important role to support lead researchers and research institutions to deal with the previous mentioned challenges of STI in Brazil.

\section{Method}

This is a descriptive and qualitative research conducted applying case study methodology (Yin, 2003). The main objective of this paper is to present two study cases that illustrate relevant initiatives in RA in Brazil: the creation of the Brazilian Research Administration and Management Association (BRAMA), and the preparation and conduction of a specialized training program by one of the most important public funding agencies in Brazil, the "Training Program for Implementation of an Institutional Support Office for Researchers (EAIP)" of the São Paulo Research Foundation (FAPESP).

The secondary objectives of this paper are: (i) discuss the importance of the institutions to the performance of the science and technology policies based on transaction costs economy approach, (ii) discuss the impact of RA activities to minimize transaction costs in research institutions and (iii) discuss the relevance of the evolvement of Research Administration to Brazil. 
The proposed discussions were conducted using as main sources of evidence academic literature, institutional websites and data provided by the studied organizations. The organizations provided voluntarily quantitative data about their operation that were important to illustrate the dimension of the cases examined. Moreover, the primary author of this paper is associated member and volunteer of working group at BRAMA and had authorized access to some internal documents that enriched the analysis.

The theoretical approach of this study is based in the transaction costs economy. According to Furuthbotn and Richter (1991, p. 3 apud Farina, Azevedo, \& Saes, 1997, p. 22), costs are not directly related to production activities, they also emerge from the problems regarding relationship and coordination in any governance structure. North (1991, p. 97 apud Farina et al., 1997) define that "institutions are standards built by human being that structure the social, economical and political interaction. They consist of informal (e. g. traditions, conduct code) and formal standards (e.g. laws)". The institutionalization of routines and a strong identity are important to the capacity building of the organizations in the network. Trust and reputation are essential to the relationships maintenance and durability, minimizing behavioral uncertainty and consequent opportunism. Trust level is directly related to providing a favorable institutional environment and governance structure to create knowledge sharing routines and minimize transaction costs (Azevedo, 2000; Dyer \& Nobeoka, 2000; Dyer \& Singh, 1998; Goussevskaia, Milagres, Luiza, Araújo, \& Tello, 2004; Williamson, 1985).

\section{Results}

\subsection{Institutional Support Office for Researchers Training Pro- gram of the São Paulo Research Foundation (FAPESP)}

São Paulo Research Foundation (FAPESP) is one of the main public funding agencies in Brazil. Only in 2017, the agency provided $\mathrm{R} \$ 429,7$ million for scholarships and $\mathrm{R} \$ 316,4$ million for research projects grants. The management of this amount of budget requires a meticulous process to enable the monitor and control of more than 10 thousand projects and scholarships (FAPESP, 2018b).

In response to the demands of the scientific community to minimize difficulties of the pre-award and post-award processes such as project submission and accountability, FAPESP created a "Training Program for Implementation of an Institutional Support Office for Researchers (EAIP)" in 2010 (FAPESP, 2018a).

The 27-hour training program has the duration of four days and attends about six participants in each class. The participants return to their institutions with the mission of implement or reorganize local processes to attend the best practices learned in the course. Additionally, they are eligible to use a priority attendance channel to clarify and solve problems and receive news about updates and improvements in the funding agency processes and requirements. After one year, the trained institution is visited by EAIP program managers that get feedback and give support in additional difficulties (FAPESP, 2018a).

In the Figure 1 it is possible to perceive the extent of EAIP program. According to information provided by FAPESP, until 2016 the program trained institutions that voluntarily contacted the foundation, but after this date, they had the initiative of contacting research institutions of São Paulo state that were not trained yet to explain the training benefits proven by the last years of experience. In the period of 2010 to 2017, FAPESP trained 538 people originated of 160 units (faculties or departments) from 43 institutions, with an average of 67 people trained per year. In total, the program performed 89 classes that totalized 2403 hours of classes in the period analyzed. The EAIP program managers visited 96 institutions after about one year of the training and identified 62 active institutional support offices according to the EAIP program website accessed in September 2018 (FAPESP, 2018a).

Figure 1. Numbers about EAIP program. Source: Data provided by FAPESP in $24^{\text {th }}$ May 2018. Charts elaborated by the author with www.visme.co.

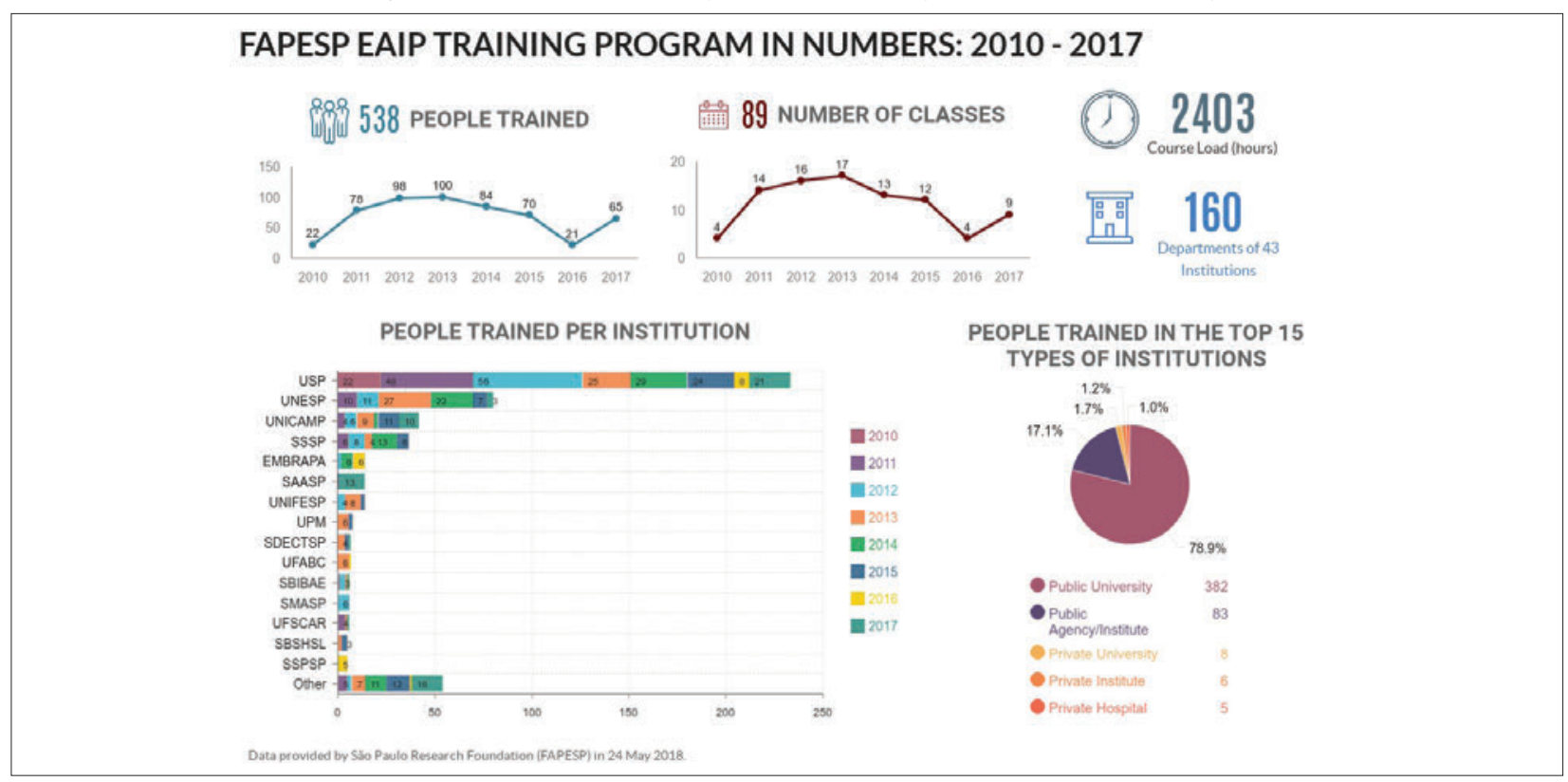

ISSN: 0718-2724. (http://jotmi.org)

Journal of Technology Management \& Innovation ( $)$ Universidad Alberto Hurtado, Facultad de Economía y Negocios. 
The content of the EAIP program course consists of: institutional information about the organization structure and main processes of the funding agency; detailed information about the types of grants, agency standards and regulations; detailed information about administrative, finance, audit and importation processes; detailed information about scientific management and research projects evaluation process; and main procedures related to the information systems used to submit proposals and monitor expenses and accountability. These subjects are directly related to operational pre and post-award processes. If we assume that the most of the participants of the training classes are working directly with the research administration of research projects, we have already identified a network of about 500 research administrators and so many experiences to be shared.

Pondering that 160 units from 43 institutions were trained until 2017 and that 1674 state research institutions are eligible to submit proposals to FAPESP (according to data collected from FAPESP Support System (SAGE) in September 2018), there are several institutions not covered by the program yet. Although the major research institutions of São Paulo state were already trained, there is space to find more research administrators and opportunities for improvement in more locations.

Marques (2014) described some successful results achieved after the implementation of the Institutional Support Office for Researchers (EAIP) in trained institutions. The Albert Einstein Jewish Institute for Education and Research (IIEP-HIAE), reported in 2014 a 61\% increase in the acceptance of projects submitted to funding agencies after two years of the support office creation. Positive outcomes were also described from Support Offices of the University of Campinas (UNICAMP) and São Paulo State University (UNESP).

\subsection{Brazilian Research Administration and Management Associ- ation (BRAMA)}

BRAMA $^{1}$ was founded in July 2013 by a group of research administrators and research managers during an Annual Meeting of the Brazilian Society for Science Progress (SBPC), held in Federal University of Pernambuco (UFPE). Due to bureaucratic delays, the regiment register was done only in June 2015. The association is sister society of SRAi and have been supported by other associations from Australia, United Kingdom, Denmark and other countries (BRAMA, 2018b).

The objectives of BRAMA are: promote development and recognition of the research manager and research administrator professionals; encourage studies and researches about scientific research management and administration; disseminate the importance of research management and administration profession; promote the exchange of knowledge and experience through meetings and events locally, nationally and internationally among members, institutions and associations; promote trainings and consulting services; advise private or public agencies (BRAMA, 2018a).
The association is in the moment of bringing their existence to the knowledge of research institutions, research administrators, research managers, and public agencies. The association is still building processes to operationalize core activities to be able to give the next step to promote paid services to guarantee their sustainability. Nevertheless, BRAMA is making efforts to be active and bringing benefits to their associated members. The main activities performed by the association since its creation are:

- Support of event about Scientific Research Management in Brazil, held in São Paulo, Albert Einstein Jewish Hospital, $10^{\text {th }}$ May 2016.

- Participation of representatives and associated members in relevant international events in the area: SRAi Annual Meeting and International Network of Research Management Societies (INORMS) since 2016.

- Participation of representatives and associated members in regional and national events, such as Research Pro-Rector Meetings.

- Submission of a proposal to co-host the 2020 INORMS congress in March 2017. The winning proposal was from the Japanese association Research Managers and Administrators Network Japan (RMAN-J) with the collaboration of the SRAi. The event is planned to happen in May 2020 and will be held in Hiroshima, Japan.

- Publicity initiatives since 2017: elaboration of a press-release document and organization of meetings with several federal and state public funding agencies.

- Creation and maintenance of a new website and a facebook page in 2017.

- The planning of the $1^{\text {st }}$ BRAMA Meeting, date and place to be defined.

- Creation of the BRAMA online training program in 2018 for associated members. The program started in March 2018 and happenned all year long, totalizing 18 classes. The bi-weekly classes were regarding relevant topics of research administration such as Brazilian law and regulations, public funding agencies regulations, scientific integrity, project management, finance management, and accountability.

Even with BRAMA director committee endeavors, the quantity of associated members in April 2018 is still low, 33 participants, as presented in Figure 2. Most of them are female and originated from private and public universities of the Brazilian Southeast region.

(1) The first president of the association, during the period of 2013-2016, was Carlos Graeff Teixeira, current Research Director at Pontifícia Universidade Católica do Rio Grande do Sul (PUCRS). Since 2017 the association is chaired by Aline Pacífico Rodrigues, current Research Support Office Manager at IIEP-HIAE. 


\section{BRAMA IN NUMBERS: April 2018}

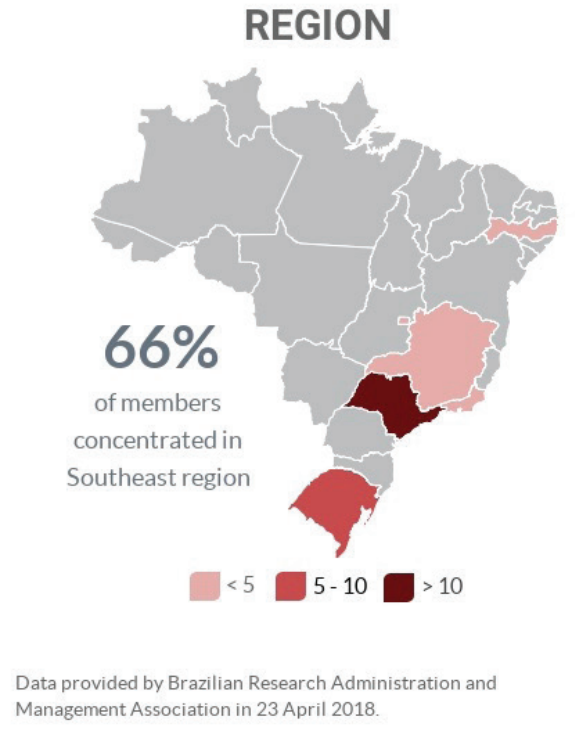

\section{NEW MEMBERS}
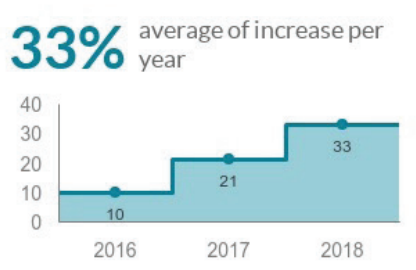

TYPE OF INSTITUTIONS

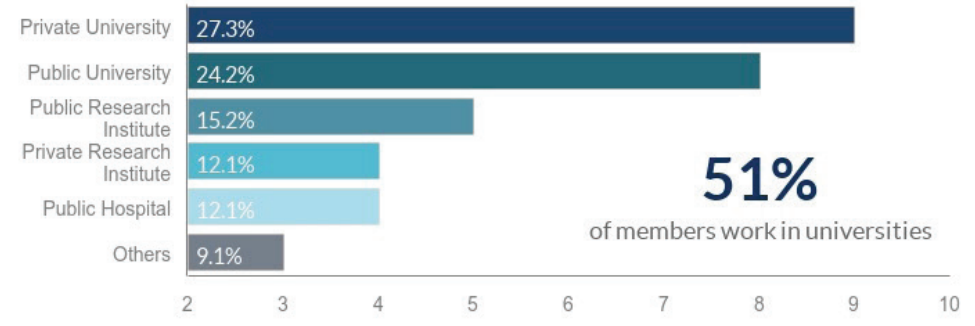

\section{Discussion}

Based in Williamson (1985) and Farina, Azevedo and Saes (1997), and complemented by RA processes identified during the literature review, the transactional costs involved in the $\mathrm{R} \& \mathrm{D}$ lifecycle are the following: partnership arrangements and negotiation, projects proposal preparation and submission, contract preparation and signing (ex-ante transaction costs); and project management and monitoring, project finance and assets administration, R\&D activities execution and follow-up, project accountability, technology transfer activities and publication of the results (ex-post transaction costs).

The unfamiliarity of the Brazilian institutions and researchers with the processes required by public agencies to receive grants or tax incentives, and the unfamiliarity with laws and regulations regarding STP establishment and related risks and uncertainty often inhibit the involved actors in doing R\&D and innovation projects collaboratively. The novelty factor of research projects difficult the trust building since rarely is possible to maintain relations with only the same partners and suppliers according to research area and type of project. These conditions are responsible for the creation of additional controls by institutions to deal with the limited rationalism, complexity, uncertainty, and opportunism, which impacts directly in the increase of transaction costs related.

The research administrator(s) is the person or group prepared to know the knowledge sharing routines including the management of partnerships, access to funding and tax incentive opportunities and the support to the lead researcher in the general administration and management of research projects. This support contributes to increase the knowledge about partners processes and public laws which contributes to the trust building and, consequently, minimize law uncertainty and transaction costs.

The process of institutionalization of RA area in Brazil have started and are relevant to the building of good practices to improve STI efficiency and also to the valorization and recognition of the RA profession.

FAPESP EAIP training program is an important initiative of trust building and minimization of transaction costs in the trained institutions. The program has already a good coverage of the major researcher institutions of São Paulo state and potential to achieve a higher number of professionals and institutions. It would be very helpful to have similar initiatives in other agencies and states.

Currentlly BRAMA does not have an expressive number of participants yet. It was already expected that the origin of them was concentrated in the Southeast region due to the number of institutions and researchers and impact of FAPESP funding opportunities in this location, since it is more expressive when compared with other state funding agencies. It is possible to infer that universities have more awareness about RA or are more organized in relation to administrating project grants and scholarships because of the predominance of members of universities in the EAIP training program and also as BRAMA member.

Even with a small number of members, it is interesting to notice that there are BRAMA members from hospitals probably because of the significant volume of research projects in the health area financed by public agencies, and also the higher complexity of management of this kind of projects that have more strict regulations due to risks related to experiences with animals and human patients. 
The association has already begun an online training program to share good practices, knowledge, and experiences that can support initiatives to implement or review processes to minimize transaction costs in the institutions of the BRAMA members.

BRAMA creation is very recent, but it is the beginning of the consolidation of the RA policy community. The scientists have been important participants of the policy arena, but we have described in this paper several difficulties regarding Brazilian laws, regulations, contracting, administrative and finance processes which it is not usually their skills. Research administrators hands-on experience can be very helpful in the STI policy analysis, for instance, as pressure force in the review of policies strategies and in the definition of new alternatives to simplify processes and minimize bureaucracy.

The findings showed that important institutional elements in Science and Technology were created in Brazil since the postwar period, some of them with an expected delay in comparison with the US due to national socioeconomic history background. Although institutionalization of science and technology policy and several initiatives to boost $\mathrm{R} \& \mathrm{D}$ and innovation in Brazil, there is a lack of governance initiatives in favor of convergence and alignment among involved actors, policies and strategies proposed. Red tape is not a national issue, but it is aggravated by the Brazilian context of disconnection between these institutional elements, which open space to opportunism and legal uncertainty.

The development of RA in Brazil is being pushed by the desire of moving national STI governance to a new level. The searching for more efficiency and impacting results is directly related to the bureaucracy and transaction costs minimization and the maturity of the STI institutional and governance structure. The researchers are usually showing, in several spheres, their discontentment in doing science in Brazil, and, it is improbable that a demotivated team will move the country to reach better STI indicators. The recognition of RA professionals permits to include important hands-on skilled actors in these discussions that pass through the scientific and technological field.

Next studies could study how RA organizational structures and practices have being implemented in Brazilian STI institutions, understand their specificities compared to developed countries and also, understand the challenges and gains of the recognition of RA profession to the national STI policy arena.

\section{Acknowledgments}

We wish to thank FAPESP and BRAMA for providing the data used in this paper.

\section{References}

Albuquerque, M. E. E., \& Bonacelli, M. B. M. (2014). A construção de rotinas e capacidades organizacionais para a viabilização de novas trajetórias nos institutos e centros de P\&D brasileiros. In M. Monteiro, C. de Campos, \& R. de B. Dias (Eds.), Novos Horizontes em Política Científica e Tecnológica (pp. 15-36). Santo André: Universidade
Federal do ABC. Retrieved from https://www.researchgate.net/profile/ Marko_Monteiro/publication/262914404_Novos_Horizontes_em_ Poltica_Cientfica_e_Tecnolgica/links/00463539333d91616e000000. pdf\#page $=15$

ARMA. (2018). Association of Research Managers and Administrators (ARMA) Website. Retrieved June 10, 2018, from https://www. arma.ac.uk/about

ARMS. (2018). Australasian Research Management Society (ARMS) Website. Retrieved June 10, 2018, from https://researchmanagement. org.au/content/about-arms/

Arrow, K. J. (1972). Economic Welfare and the Allocation of Resources for Invention. Readings in Industrial Economics, 219-236. https:// doi.org/10.1007/978-1-349-15486-9_13

Azevedo, P. F. (2000). Nova economia institucional: referencial geral e aplicações para a agricultura. Agricultura Em São Paulo, 47(1), 33-52. Bastos, V. D. (2003). Fundos Públicos para Ciência e Tecnologia. Revista Do BNDES, 10(20), 229-260.

Beasley, K. L. (2006). The History of Research Administration. In E. C. Kulakowski \& L. U. Chronister (Eds.), Research Administration and Management (pp. 9-29). London: Jones \& Bartlett Publishers.

Bin, A., Gianoni, C., Mendes, P. J. V, Rio, C., Salles-filho, S. L. M., \& Capanema, L. M. (2013). Organization of Research and Innovation : a Comparative Study of Public Agricultural Research Institutions. Journal of Technology Management \& Innovation, 8(Special Issue ALTEC), 209-218. https://doi.org/https://doi.org/10.4067/s071827242013000300048

Bin, A., \& Salles-filho, S. (2008). Science, Technology and Innovation Management: Specificities and Conceptual Premises. International Joseph A. Schumpeter Society Conference-the Southern Conference, (i), 1-25. Retrieved from https://www.researchgate.net/profile/Sergio_ Salles-Filho/publication/255649466_SCIENCE_TECHNOLOGY_ AND_INNOVATION_MANAGEMENT_SPECIFICITIES_AND_ CONCEPTUAL_PREMISES/links/556e665908aeccd7773f6e3f.pdf

Bonvillian, W. B. (2014). The new model innovation agencies: An overview. Science and Public Policy, 41(4), 425-437. https://doi. org/10.1093/scipol/sct059

BRAMA. (2018a). Brazilian Research Administration and Management Association (BRAMA). Retrieved September 1, 2018, from http://www.bramabrazil.org/

BRAMA. (2018b). Brazilian Research Administration and Management Association Press Release. BRAMA.

Bush, V. (1945). Science: The Endless Frontier. Transactions of the Kansas Academy of Science, 48(3), 34. Retrieved from https://www. nsf.gov/od/lpa/nsf50/vbush1945.htm 
CARA. (2018). Canadian Association of Research Administrators (CARA) Website. Retrieved June 10, 2018, from https://cara-acaar.ca/about

Carvalho, F. P. de. (2010). Cooperação e alianças para a inovação e o desempenho das empresas brasileiras. In M. Sergio Salerno, J. Alberto de Negri, L. Maria Turchi, \& J. Mauro de Morais (Eds.), Inovação: Estudo de jovens pesquisadores brasileiros (1a. Edição, pp. 465-484). São Paulo: Editora Papagaio.

CAURA. (2018). Canadian Association of University Research Administrators (CAURA) Website. Retrieved June 10, 2018, from http:// www.caura-acaru.ca/contact-us/

Chesbrough, H. (2006). Open Innovation: A New Paradigm for Understanding Industrial Innovation. In H. Chesbrough, W. Vanharvebeke, \& J. West (Eds.), Open Innovation Researching a New Paradigm (pp. 1-12). New York: Oxford University Press.

CONFIES, MCTIC, \& SEBRAE. (2017). O que pensa o pesquisador brasileiro sobre a burocracia? Brasília. Retrieved from http://confies. org.br/institucional/wp-content/uploads/2017/03/pesquisa_o_que_ pensa_o_pesquisador.pdf

Cunningham, J., O’Reilly, P., O’Kane, C., \& Mangematin, V. (2014). The inhibiting factors that principal investigators experience in leading publicly funded research. Journal of Technology Transfer, 39(1), 93-110. https://doi.org/10.1007/s10961-012-9269-4

DARMA. (2018). Danish Association of Research Managers and Administrators (DARMA) Website. Retrieved June 10, 2018, from http://www.darma.dk/page-1860221

De Negri, F., \& Squeff, F. de H. S. (2014). Infraestrutura científica e tecnológica no Brasil: análises preliminares. Brasília: Instituto de Pesquisa Econômica Aplicada. Retrieved from http://repositorio.ipea. gov.br/bitstream/11058/5761/1/NT_n21_Infraestrutura-cientificatecnologica-Brasil_Diset_2014-jun.pdf

De Negri, F., Zucoloto, G. F., Squeff, F. H. S., \& Rauen, A. T. (2016). Inovação no brasil: crescimento marginal no período recente. Retrieved from http://www.ipea.gov.br/portal/images/stories/PDFs/nota_ tecnica/20161209_nt_34.pdf

Dyer, J. H., \& Nobeoka, K. (2000). Creating and Managing a High Performance Knowledge-Sharing Network: The Toyota Case. Strategic Management Journal, 21(3), 345-367. https://doi.org/10.1002/ (SICI)1097-0266(200003)21:3<345::AID-SMJ96>3.0.CO;2-N

Dyer, J. H., \& Singh, H. (1998). The Relational View: Cooperate Strategy and Sources of Interorganizational Competitive Advantage. The Academy of Management Review, 23(4), 660-679. https://doi. org/10.7880/abas.13.77

EARIMA. (2018). Eastern African Research and Innovations Management Association (EARIMA) Website. Retrieved June 10, 2018, from http:// www.earima.net/images/Files/SAVE_THE_DATE_EARIMA_2017.pdf
EARMA. (2018). European Association of Research Managers and Administrators (EARMA) Website. Retrieved June 10, 2018, from http://www.earma.org/about/

EUPMAN. (2018). Association for Research Managers and Administrators - the Netherlands (ARMA-NL) Website. Retrieved September 23, 2018, from https://www.eupman.eu/Home.html

FAPESP. (2018a). Escritório de Apoio Institucional ao Pesquisador (EAIP). Retrieved September 22, 2018, from http://www.fapesp. br/eaip

FAPESP. (2018b). Sobre a FAPESP. Retrieved September 22, 2018, from http://www.fapesp.br/sobre/

Farina, E. M. M. Q., Azevedo, P. F. De, \& Saes, M. S. M. (1997). A Nova Economia Institucional. In Competitividade: mercado, estado e organizações (pp. 1-70). São Paulo: Singular.

Finn-ARMA. (2018). Finnish Association of Research Managers and Advisors (Finn-ARMA) Website. Retrieved September 5, 2018, from http://www.finn-arma.fi/

Galaskiewicz, J. (1985). Professional Networks and the Institutionalization of a Single Mind Set. American Sociological Review, 50(5), 639. https://doi.org/10.2307/2095379

Goussevskaia, A. A., Milagres, R., Luiza, A., Araújo, L. De, \& Tello, R. (2004). Inovação Interativa: Capital Social , Knowledge Sharing Routines e Formação de Redes Interorganizacionais. Caderno de Idéias, (October 2005), 1-16.

Hagedoorn, J. (2002). Inter-firm R\&D partnerships: an overview of major trends and patterns since 1960. Research Policy, 31(4), 477-492. https://doi.org/10.1016/S0048-7333(01)00120-2

IBGE. (2016). Pesquisa de Inovação 2014 (Pintec). Rio de Janeiro: Instituto Brasileiro de Geografia e Estatística (IBGE). Retrieved from http://www.pintec.ibge.gov.br/downloads/PUBLICACAO/PUBLICAÇÃO PINTEC 2014.pdf

ICEARMA. (2018). Icelandic Association for Research Managers and Administrators (ICEARMA) Website. Retrieved June 10, 2018, from http://icearma.is/felagatal-2018/

INORMS. (2018). International Network of Research Management Societies (INORMS) Website. Retrieved October 6, 2018, from http:// www.inorms.net/members.html

Kerridge, S., \& Scott, S. (2018). Research Administration around the world. Research Management Review, 23(1), 1-34.

Kulakowski, E. C., \& Chronister, L. U. (2008). The Future of Research Administration in the 21st Century: Looking into the Crystal Ball. In E. C. Kulakowski \& L. U. Chronister (Eds.), Research Administration and Management (p. 916). Davis, California: Jones \& Bartlett Publishers. 
Landen, M., \& McCallister, M. (2008). The Research Administrator as a Professional: Training and Development. In E. C. Kulakowski \& L. U. Chronister (Eds.), Research Administration and Management (p. 916). Davis, California: Jones \& Bartlett Publishers.

Marques, F. (2014). Ambiente adverso. Revista Pesquisa FAPESP, 2015, 36-39. Retrieved from http://revistapesquisa.fapesp.br/2014/01/13/ ambiente-adverso/

MCTIC. (2018). Indicadores Consolidados 2000-2015. Retrieved September 26, 2018, from https://www.mctic.gov.br/mctic/opencms/ indicadores/detalhe/recursos_aplicados/indicadores_consolidados/2_1_3.html

Monteiro, V. (2017, January 27). Burocracia consome mais de 30\% do tempo dos cientistas, constata pesquisa. Jornal Da Ciência. Retrieved from http://www.jornaldaciencia.org.br/burocracia-consome-maisde-30-do-tempo-dos-cientistas-constata-pesquisa/

Morel, R. L. de M. (1979). Ciência e Estado: a política científica no Brasil. São Paulo: T. A. Queiroz Editor.

NARMA. (2018). Norwegian Network for Administration and Research Management (NARMA) Website. Retrieved June 10, 2018, from http://narma.no/om-narma/english-about-narma-and-contact/ Narula, R., \& Zanfei, A. (2005). Globalization of Innovation: the role of multinational enterprises. In J. Fagerberg, D. C. Mowery, \& R. R. Nelson (Eds.), The Oxford handbook of innovation (pp. 318-347).

New York: Oxford university press. Retrieved from https://books. google.com.br/books?hl=pt-BR\&lr=\&id=y7oSDAAAQBAJ\&oi=fn $\mathrm{d} \& \mathrm{pg}=\mathrm{PR} 9 \& \mathrm{dq}=+\% 22 \mathrm{Oxford}+$ Handbook + of + Innovation $\% 22 \&$ ot $\mathrm{s}=\mathrm{z6R}$ 5NP__2a\&sig=3Z60lpynB9bCaTeKgcnv2aGxfNk\#v=onepa ge\&q=\%22Oxford Handbook of Innovation $\% 22 \& f=$ false

NCURA. (2018). National Council of University Research Administrators (NCURA) Website. Retrieved June 10, 2018, from http://www. ncura.edu/AboutUs.aspx

OECD. (1992). Technological innovation: some definitions and building blocks. Technology and the Economy - The Key Relationships, (Chapter 1), 23-45.

OECD. (2016). OECD Science, Technology and Innovation Outlook 2016. https://doi.org/10.1787/sti_in_outlook-2016-en

Oliveira, F. S. de, Bambini, M. D., Spatti, A. C., \& Ito, R. (2017). DINÂMICA DA FORMAÇÃO DE REDES DE PD\&I: A EXPERIÊNCIA DA EMBRAPA INFORMÁTICA AGROPECUÁRIA NA ARTICULAÇÃO DE PARCERIAS PÚBLICO-PRIVADAS (PPP). In VI SINGEP - Simpósio Internacional de Gestão de Projetos, Inovação e Sustentabilidade. São Paulo-SP, Brazil.

Oliveira, J. J. De. (2016). Ciência, tecnologia e inovação no Brasil: poder, política e burocracia na arena decisória. Revista de Sociologia e Política, 24(59), 129-147. https://doi.org/10.1590/1678-987316245907
Pacheco, C. A. (2011). O financiamento do gasto em P\&D do setor privado no Brasile o perfil dos incentivos governamentais para P\&D. Revista USP. São Paulo: Revista USP. Retrieved from http://rusp.scielo.br/ scielo.php?script=sci_arttext\&pid=S0103-99892011000200018\&lng $=$ pt\&nrm $=$ iso

Pacheco, C. A., Bonacelli, M. B. M., \& Foss, M. C. (2017). Políticas de estímulo à demanda por inovação e o Marco Legal de CT\&I. In D. R. Coutinho, M. C. Foss, \& P. S. B. Mouallem (Eds.), Inovação no Brasil: avanços e desafios jurídicos e institucionais (pp. 213240). São Paulo: Blucher Open Access. https://doi.org/https://doi. org/10.5151/9788580392821-08

RACC. (2018). Certified Research Administration Body of Knowledge (CRABoK). Retrieved September 26, 2018, from http://www.cracert.org/cra-body-of-knowledge/

RMAN-J. (2017). Research Manager and Administrator Network Japan (RMAN-J) Presentation. Retrieved June 10, 2018, from http:// web.teamsites.ntu.edu.sg/rso/Documents/NTU RA Conference 2017/ Japanese Research Managers and Administrators on the Move.pdf

Salles-Filho, S., \& Bonacelli, M. B. M. (2010). Science and Public Policy Trends in the organization of public research organizations: lessons from the Brazilian case. Science and Public Policy, 37(3), 193 204. https://doi.org/10.3152/030234210X497708

Salles-Filho, S. L. M., Bonacelli, M. B. M., \& Mello, D. L. (2000). Metodologia para o Estudo da Reorganização Institucional da Pesquisa Pública. Parcerias Estratégicas, 9, 86-108.

SARIMA. (2018). Southern African Research and Innovation Management Association (SARIMA) Website. Retrieved June 10, 2018, from http://www.sarima.co.za/

SBPC. (2016). Relatório de Atividades 2013-2015. São Paulo: Sociedade Brasileira para o Progresso da Ciência. Retrieved from http://www. sbpcnet.org.br/site/arquivos/relatorio_2013_2015.pdf

SJR. (2018). SJR - International Science Ranking. Retrieved September 26, 2018, from https://www.scimagojr.com/countryrank.php

SRAi. (2018). Society of Research Administrators International (SRAI) Website. Retrieved June 10, 2018, from https://srainternational.org/about-sra-international

Streete, T., Henry, M., Ivey, P., \& Oliver, G. (2013). A case study on the state of research management in the Caribbean. Regional and Thematic Papers on Research Management 2009-2013, (2013). Retrieved from https://www.acu.ac.uk/publication/download?publication $=537$

URIMA. (2018). Uganda Research and Innovation Management Association (URIMA) Registration. Retrieved June 10, 2018, from https://opencorporates.com/companies/ug/80010000773743 
WARIMA. (2018). West African Research and Innovation Management Association (WARIMA) Project Page. Retrieved June 10, 2018, from https://www.acu.ac.uk/focus-areas/research-management-uptake/warima

Weinberg, A. M. (1961). Impact of Large-Scale Science on the United States. Science, 134(3473), 161-164. Retrieved from https://www. jstor.org/stable/1708292

Williamson, O. E. (1985). The Economic Institutions of Capitalism. Firms, Markets, Relational Contracting. New York: The Free Press.
Wright, M. (1988). Policy Community, Policy Network and Comparative Industrial Policies. Political Studies, 36(4), 593-612. https://doi. org/10.1111/j.1467-9248.1988.tb00251.x

Yin, R. K. (2003). Case Study Research - Design and Methods. London: SAGE Publications. https://doi.org/10.1097/FCH.0b013e31822dda9e 